\title{
有限要素法によるガラスレンズのプレス成形シミュレーション*
}

\author{
荒井 政 ${ }^{* 1}$, 山 本 和 也 ${ }^{* 2}$, 中村 淳之介*3
}

伊藤寛 明*3, 松 倉 利 顕 ${ }^{* 4}$, 杉本 公一*1

\section{Numerical Simulation of Forming Process of Glass-Lens Using Finite Element Method}

\author{
Masahiro ARAI*5, Kazuya YAMAMOTO, Junnosuke NAKAMURA, \\ Hiroaki ITO, Toshiaki MATSUKURA and Ko-ichi SUGIMOTO \\ ${ }^{* 5}$ Department of Mechanical Systems Engineering, Shinshu University, \\ 4-17-1 Wakasato, Nagano-shi, Nagano, 380-8553 Japan
}

\begin{abstract}
In the present paper, numerical simulation about press forming process of glass lens using finite element method is investigated. It is well known that constitutive equation (elastic constants) of glass depend on time-history and temperature. Therefore, stress relaxation or creep arise on the glass subjected to applied loading, and these behaviors vary drastically depending on the temperature. In the present study, creep test has been conducted to determine the thermo-viscoelastic properties of glass. The creep function obtained by the experiment has been transformed into relaxation function employing Laplace transform and its inversion. Shift factor which gives the relation between the time and temperature can be determined by creep test under several temterature, too. Using typical glass "TaF-3" which has been used for press forming, some numerical simulation by FEM are demonstrated. Residual stresses and residual deformations under some processing conditions are estimated, and the optimal conditions of forming process for glass lens are discussed in detail.
\end{abstract}

Key Words: Finite Element Method, Numerical Analysis, Thermo-Viscoelasticity, Creep Test, Laplace Transform, Constitutive Equation, Press Forming, Glass Lens

\section{1. 緒論}

デジタルカメラや㩲帯電話などの民生機器分野, 内 視鏡に代表される医療分野，分析機器分野など，ガラ ス製光学レンズおよびガラス製光学デバイスの用途は 年々扡大しており, その高機能化・高精度加工化への 要求もさらに高まりつつある. そのなかで, ガラスレ ンズの生産コストの低减, 成形の高度化への要求から, 金型を用いた高温プレス成形による製造法が開発され， 注目を集めるようになった ${ }^{(1)}$. プレス成形によるレン ズ製造法は, 従来の研磨法に比べ大量生産に向く方法 であり, かつ非球面レンズの加工が容易であるといっ た利点を有している.

しかしながら，ガラスレンズのプレス成形に関する 最適条件の把握は，一般に多くの困難を伴う. 例えば プレス成形過程の数值シミュレーションを行うことを 考えると, 金型とガラス材の非線形接触・大変形問題

* 原稿受付 2005 年 8 月 22 日.

*1 正員, 信州大学工学部 ( $380-8553$ 長野市若里 4-17-1).

*2 信州大学大学院工学系研究科 [現：オリンパスイメージン グ (株) (163-0914 東京都新宿区西新宿 2-3-1)].

*3 信州大学大学院工学系研究科.

*4 チノンテック (株) (392-0015 諏訪市中洲 4710).

E-mail : arai@shinshu-u.ac.jp
となるだけでなく, ガラスの弾性係数が温度と時間に 依存する熱粘弾性体であることを考虑する必要がある. また, ガラスレンズと金型との接触条件が時々刻々と 変化するため, ガラス内部の温度変化を正確に把握す ること難しい. 以上のように, 数值計算的な取り扱い が非常に難しい問題であることから，ガラスレンズの プレス成形を解析的に取り扱った研究は, ほとんど報 告されていないのが現状である.

これらの状況に鑑み, 著者らのグループは, 数值解 析を可能するための幾つかの仮定を設けながらも，カ ラスレンズのプレス成形を有限要素シミュレーション より評価し, 一連の成果を得た ${ }^{(2)}$. その結果, 成形さ れたガラスレンズの形状寸法および残留応力は, ガラ スの熱粘弾性特性 ${ }^{(3)}{ }^{(4)}$ に起因して, 成形時間や成形圧 力に強く依存することを見出している.

しかしながら既報 ${ }^{(2)}$ の数值シミュレーションでは, 一 軸圧縮試験により得られたクリープ関数からの緩和弾 性率の決定に用いた計算アルゴリズムが十分に煮つめ られておらず, その同定精度にやや課題を残していた. そこで本研究では, 緩和弾性率の同定法に改良を施し, 解析結果の信頼性をさらに向上させるとともに，実際 のガラスレンズの成形条件に近い成形条件下での数值 


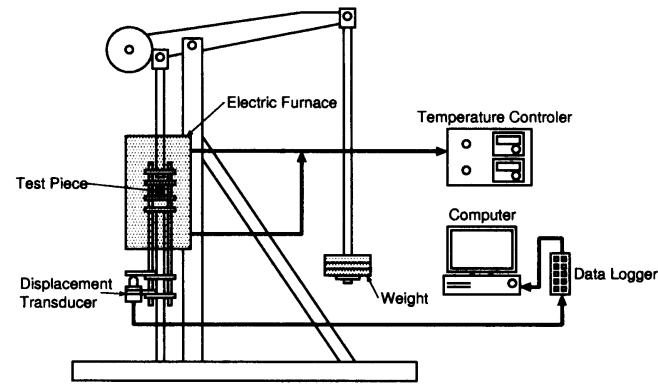

Fig.1 Schematic of creep test.

シミュレーションを実施して，ガラスレンズに発生す る残留応力ならびに残留変形に対する成形パラメータ の影翠を明らかにすべく，より詳細な検討を行った。

ガラス材料の緩和弾性率の近似には, 11 自由度を有 する一般化 Maxwell モデル(5)を新たに適用した. 測定 されたクリープ関数にべき関数の多項式近似を適用し， さらに解析的な Laplace 変換を施すことによって緩和 弾性率の同定精度の向上を図った．また，熱分析装置 を用いてガラスの線膨張係数の測定を行うことにより， 線膨張係数の近似精度の改善を図った。ささらには，単 純な熱伝導場の解析を実施して，ガラス試料内部の温 度分布の影警について考察を加えた。

代表的なプレス成形用のガラス材料である TaF-3 を 対象として，2 種の成形条件を模擬した数值シミュレー ションを実施し, 成形後に発生する残留応力, 残留変 形に着目して，プレス成形の最適条件について詳細な 考察を行った.

\section{2. 材料特性の測定}

$2 \cdot 1$ ガラス材料のクリープ試験 一般に粘弾 。 性体の構成方程式を実験的に求める方法には, 調和外 力を作用させた場合の変位応答より算出する方法と， クリープ試験を実施して算出する方法の 2 通りがある. なお，プラスチックやガラスなど，粘性的性質を示す ほとんどの材料は，その粘性挙動が温度に依存する熱 粘弾性体である.よって, 種々の温度環境下において 同様の試験を実施し, 温度一時間換算則 ${ }^{(6)(7)}$ を表すシ フトファクターの計測を行う必要がある。

緩和弾性率の測定には，もちろん一般の粘弾性測定 器を用いることも可能である．しかしながら市販の測 定装置は，そのほとんどが高分子材料を対象としてい ることから，測定温度の上限がやや低く，ガラスの測 定には適さない場合が多い，そこで本研究では既報 ${ }^{(2)}$ と同様，クリープ試験装置を用いてガラス材料の熱粘 弾性特性を同定することとした.
Table 1 Specification of glass specimen TaF-3.

\begin{tabular}{llr}
\hline Glass transition temp. & $T_{g}\left[{ }^{\circ} \mathrm{C}\right]$ & 680 \\
Density & $\rho\left[\mathrm{kg} / \mathrm{m}^{3}\right]$ & 4711 \\
Young's Modulus & $k_{0}[\mathrm{GPa}]$ & 124.8 \\
\hline
\end{tabular}

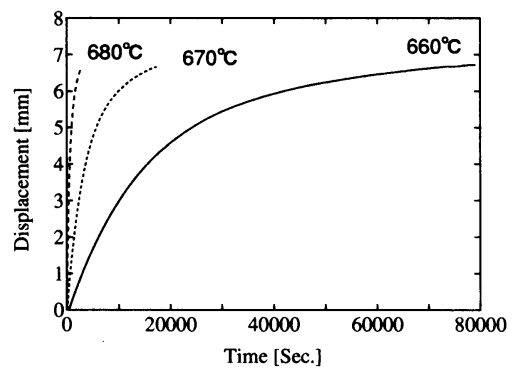

Fig.2 Experimental result of creep test using TaF-3.

・クリープ試䀦装置の概略は図 1 に示すとおりである. 電気炬の温度はコントローラーにより制御されており, そのなかに直径 $10[\mathrm{~mm}]$, 長さ $10[\mathrm{~mm}]$ の円柱形の試鍳 片が置かれている.この試験装置は一般的な引張試験 用の装置であり, 治具を用いて引張荷重を圧縮荷重に 変換することにより試験を実施した. 重錘を用いて試 験片に一定の荷重 $(98.1[\mathrm{~N}]$, 応力:1.25[MPa]) を作用 させ, その際の変位の時刻歴を計測した。

今回, 計測試料には, ガラスレンズに用いられる代 表的なガラス材として TaF-3 を用いた. TaF-3 のガラ ス転移温度, 密度, ヤング率 (瞬間弾性率) のデータを 表 1 に示す.

試験温度 $660\left[{ }^{\circ} \mathrm{C}\right], 670\left[{ }^{\circ} \mathrm{C}\right]$ および $680\left[{ }^{\circ} \mathrm{C}\right]$ における TaF-3 材のクリープ試験結果を図 2 に示す. なお, 実 際には $690^{\circ} \mathrm{C}$ においてもクリープ試䍄を実施している が, 変形が極めて短時間で終了するため, その際の結 果は図 2 には含めていない. クリープ試験結果に示さ れているように, 同一の変形量に達するまでの時間が, 試垔温度の上昇とともに短くなっていることがわかる.

$2 \cdot 2$ 綬和弾性專の決定線形粘弾性理論によ れば，粘弾性体に作用する応力 $\sigma(t)$ とひずみ $\varepsilon(t)$ の 関係式，すなわち構成方程式は以下のような畳み込み 積分により記述することができる(2)(8)

$$
\sigma(t)=\int_{0}^{t} k(t-\tau) \frac{d}{d \tau} \varepsilon(\tau) d \tau+k(t) \varepsilon(0) \ldots \ldots
$$

ここで $k(t)$ は緩和弾性率であり, $t=0$ において単位 ステップ状のひずみ入力が作用したときの忘力の時間 変動を意味する. この式を, 単位ステップ状の応力が作 用したときのひずみ応答，すなわちクリープ関数 $J(t)$ を用いて書き直すと以下のようになる. 


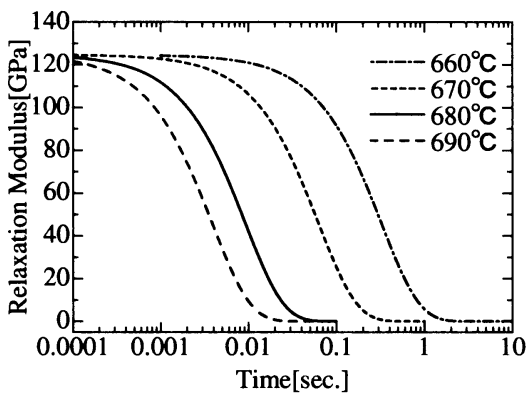

Fig.3 Relaxation modulus $k(t)$ of TaF-3.

$$
\varepsilon(t)=\int_{0}^{t} J(t-\tau) \frac{d}{d \tau} \sigma(\tau) d \tau+J(t) \sigma(0)
$$

式(1)および式 (2)にLaplace変換を施すと次式を得る.

$$
\bar{\sigma}(s)=\bar{k}(s) \bar{\varepsilon}(s), \quad \bar{\varepsilon}(s)=\bar{J}(s) \bar{\sigma}(s)
$$

ここで, $s$ は Laplace 変換パラメータであり, 各物理 量の Laplace 変換を上付き添字 ‘’’ にて示した. よっ て, 式 (3) よりクリープ関数の Laplace 変換 $\bar{J}(s)$ と 緩和弾性率の Laplace 変換 $\bar{k}(s)$ には以下の関係が成 立することがわかる.

$$
\bar{k}(s)=\frac{1}{s^{2} \bar{J}(s)}
$$

よって対象材料のクリープ関数が実験により得られれ ば， Laplace 変換を適用することにより解析に必要な 緩和弾性率を容易に求めることができる．しかしなが らこれらの演算は，Laplace 像空間上の演算および数 値的な Laplace 逆変換の過程を経るため, 一般に悪条 件下の逆問題となり，多くの諟差が重畳する.

そこで本報では，実䀦により得られたクリープ関数 をべき関数を用いて近似したのち，解析的な Laplace 変換を施し，像空間上にて式 (4) で定義される演算を 行い，数值 Laplace 逆変換 ${ }^{(9)}$ を行うことでガラス材料 の緩和弾性率を算出する手法について新たに提案する. まず，実䀫により測定されたクリープ関数を，以下の ようにべき級数和により近似する.

$$
J(t)=\sum_{i=1}^{N} a_{i} t^{i}+\frac{1}{k_{0}}
$$

ただし， $k_{0}$ は瞬間弾性率，すなわち室温でのヤング率 である.また, べき関数の次数 $N$ は 10 とした．上式 を Laplace 変換すると, 以下の式となる.

$$
\bar{J}(s)=\sum_{i=1}^{N} a_{i} \frac{i !}{s^{i+1}}+\frac{1}{s k_{0}}
$$

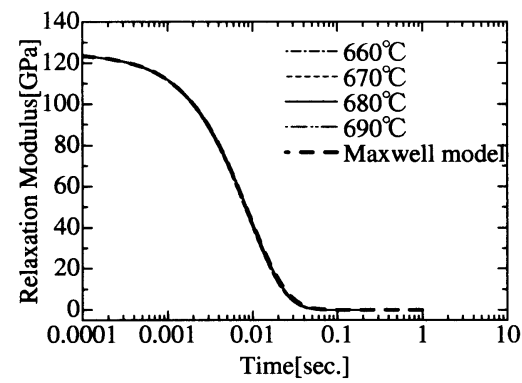

Fig.4 'Shifted' relaxation modulus for each temperatures and identified master curve using Maxwell model.

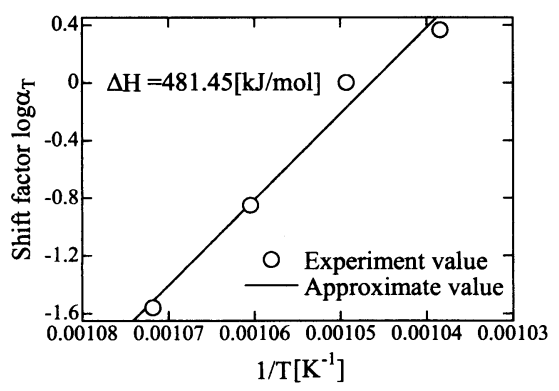

Fig.5 Shift factor of TaF-3 estimated by creep test.

すなわち，式(6)より，緩和弾性率の Laplace 変換 $\bar{k}(s)$ は以下のように求められる.

$$
\bar{k}(s)=\frac{1}{s^{2}\left\{\sum_{i=1}^{N} a_{i} \frac{i !}{s^{i+1}}+\frac{1}{s k_{0}}\right\}}
$$

結果として得られた $\bar{k}(s)$ に対して数值 Laplace 逆変 換 ${ }^{(9)}$ を適用すれば，実時間上の緩和弾性率 $k(t)$ が得ら れる。

図 3 は, 以上の手順に従い各測定温度における緩和 弹性率を求め, 横軸を時閒の対数として図示したもの である. グラフに示されているように，各温度の緩和 弾性係数はまったくの相似形であり, 対数時間軸上に おいて平行移動することにより，一本のカーブにまと められることがわかる. すなわち後節で述べるように， これらの平行移動量=シフト量を定量的に表せば，温 度の効果を時間に置き換えて取り扱うことができ，温 度変化を伴う熱粘弾性体の解析を简便に行うことが可 能となる.

$2 \cdot 3$ シフトファクターの決定＼cjkstart前節で述べた ように，基準温度における緩和弾性率，すなわちマス ターカーブが与えられれば，その他の温度および時間 における緩和弾性率はマスターカーブの平行移動によ り表される. 図 3 のグラフにおける $680\left[{ }^{\circ} \mathrm{C}\right]$ の曲線を 


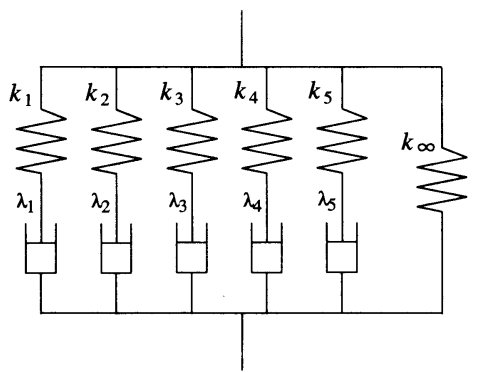

Fig.6 Maxwell model for viscoelastic materials.

基準とし, その曲線に重なるように他の温度のグラフ を平行移動させた場合の結果が図 4 である. なお, 図 4 には Maxwell モデルにより近似された曲線を併記し ているが，それについては後節にて詳しく述べる.

図 4 における時間軸方向の移動量 $\log \alpha_{T_{0}}$ を綐軸に, 絶対温度の逆数を横軸にとって整理した結果が図 5 で ある. グラフより, シフトファクターの測定データはほ ほ一次直線的に並んでいることが確かめられる．よっ て, Narayanaswamy ${ }^{(10)}$ の定義式を用いれは，粘性流 動速度の活性化エネルギー $\Delta H$ とシフトファクター $\alpha_{T_{0}}$ を次式により関係づけることができる.

$$
\ln \alpha_{T_{0}}(T)=\frac{\Delta H}{R}\left(\frac{1}{T_{0}}-\frac{1}{T}\right)
$$

ここで, $R$ は気体定数 $\left(=8.31 \times 10^{-3}[\mathrm{~kJ} / \mathrm{mol}]\right)$ であ る. また, $T_{0}$ は基隻温度であり, 本解析ではガラス転 移温度 $953[\mathrm{~K}]$ となる.

図 5 の各点を最小二乗法により一次近似し，その傾 きを求めることにより, $\Delta H=481.45[\mathrm{~kJ} / \mathrm{mol}]$ を得 た. 最終的に, 近似直線により求められた活性化エネ ルギーを式 (8) に代入することにより, 任意の温度に おけるシフトファクターを求めることができる.

2.4 Maxwell モデルによる綬和弾性率の近似 本論文では, クリープ試鮯により求められた緩和弾性 率を, Maxwell モデルを用いて近似する. 今回用いた Maxwell モデルは, 図6に示されるような弾性要素と

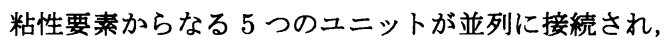
さらに時刻無限大に対応する弾性要素 $k_{\infty}$ が付加され た計 11 自由度のモデルである. このモデルの緩和弾性 率 $k(t)$ は次式により表される.

$$
k(t)=\sum_{i=1}^{5} k_{i} \exp \left(\frac{-t}{\lambda_{i}}\right)+k_{\infty}
$$

ここで $k_{1}, k_{2}, \ldots, k_{5}$ および $\lambda_{1}, \lambda_{2}, \ldots, \lambda_{5}$ は Maxwell モデルの各要素に対応する未定俰数, $k_{\infty}$ は無限時間 経過後の弾性率をそれぞれ表す。

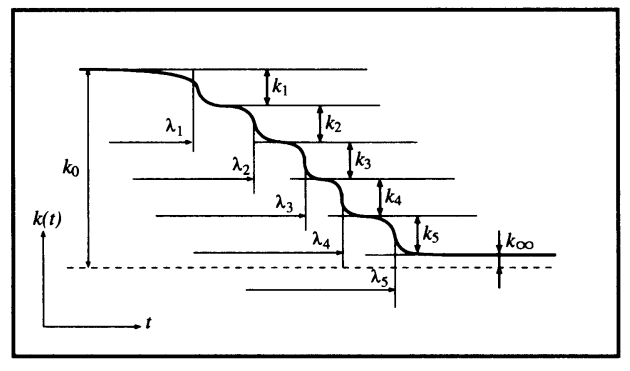

Fig.7 Example image of relaxation modulus approximated by Maxwell model.

図 6 のモデルにより近似された緩和弾性率を模式 的に示したのが図 7 であり，時間の経過とともに各ユ ニット $\left(k_{i}, \lambda_{i}\right)$ 毎に段階的に緩和が生じ，最終的に $k_{\infty}$ 一と収束する.よって本論文における近似では， $k_{1}$, $\cdot k_{2}, \ldots, k_{5}$ については既知量として与え，緩和速度を規 定する $\lambda_{1}, \lambda_{2}, \ldots, \lambda_{5}$ のみを未知パラメータとして探 索を行った. なお, 時刻無限大における弾性率 $k_{\infty}$ は, クリープ試䍄をさらに継続し, 十分に時間が経過した 後における試輸片の最終形状より求めることができる. また, すべての弾性係数は，瞬間弾性率 $k_{0}$ との間に成 立する以下の条件式

$$
k_{0}=\sum_{i=1}^{5} k_{i}+k_{\infty}
$$

を満たすべきことに注意されたい，以上の手順により， 残る未知量である $\lambda_{1}, \lambda_{2}, \ldots, \lambda_{5}$ に関して探索計算を 実行することにより，最終的に緩和弾性率の Maxwell モデルが同定できる.

ガラス転移温度 $T_{g}=680\left[{ }^{\circ} \mathrm{C}\right]=953[\mathrm{~K}]$ の緩和弾性 率に対してカーブフィッティングを行うことにより求め られた Maxwell モデルのマスターカーブを, 先の図 4 のグラフ中に破線にて示す. 同定された Maxwell モデ ルの曲線は，シフトされた各温度の緩和弾性率とほほ 一致していることから，本モデルにより高い近似精度 が達成されていることがわかる.

最終的に同定された Maxwell モデルにおける諸定数 は以下のとおりである.

$$
\begin{aligned}
& k_{1}=k_{2}=k_{3}=k_{4}=30.88[\mathrm{GPa}], k_{5}=1.248[\mathrm{GPa}], \\
& k_{\infty}=1.97[\mathrm{MPa}], \\
& \lambda_{1}=7.0[\mathrm{~ms}], \lambda_{2}=9.0[\mathrm{~ms}], \lambda_{3}=10.0[\mathrm{~ms}] \\
& \lambda_{4}=11.0[\mathrm{~ms}], \lambda_{5}=30.0[\mathrm{~ms}]
\end{aligned}
$$

2.5 線膨镸事の測定 ガラス試料 $\mathrm{TaF}-3$ の線 膨張係数を，熟分析測定装置 (TA50-WS; 島津製作所) により測定した. 図 8 の○印は測定された温度と熱ひ 


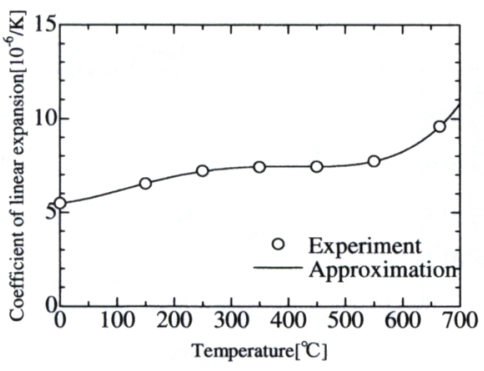

Fig. 8 Coefficient of thermal expansion.

ずみの関保を示している. グラフに示されているよう に, 室温から $700\left[{ }^{\circ} \mathrm{C}\right]$ の範囲において, 線膨張係数は 温度に依存することがわかる. そこで, 計測データに 4 次の線形多項式近似を適用し, 以下の上うに線膨張 係数を近似することとした.

$$
\rho(T)=\alpha_{0}+\alpha_{1} T+\alpha_{2} T^{2}+\alpha_{3} T^{3}+\alpha_{4} T^{4}
$$

ここで, 倸数 $\alpha_{0}, \alpha_{1}, \ldots, \alpha_{4}$ には以下の值を用いた.

$$
\begin{aligned}
& \alpha_{0}=5.48 \times 10^{-6}\left[\mathrm{~K}^{-1}\right], \alpha_{1}=3.16 \times 10^{-9}\left[\mathrm{~K}^{-2}\right] \\
& \alpha_{2}=4.87 \times 10^{-11}\left[\mathrm{~K}^{-3}\right], \alpha_{3}=-1.78 \times 10^{-13}\left[\mathrm{~K}^{-4}\right] \\
& \alpha_{4}=1.69 \times 10^{-16}\left[\mathrm{~K}^{-5}\right]
\end{aligned}
$$

\section{3. 数值シミュレーション}

$3 \cdot 1$ 解析モデル 以下, ガラスレンズのプレ ス成形シミュレーションの結果について示す. 解析モ デルは図 9 に示されるような, 直径 $10[\mathrm{~mm}]$ の球形の ガラス試料と, 上下 2 つ金型からなるモデルであり, 曲率半径 $25[\mathrm{~mm}]$ の球面レンズの成形を取り扱った.

解析では, 図9(右)のような軸対称モデルを用い, 四 角形 2 次要素を用いてガラズ材を 347 要素, 金型部分 を 479 要素の合計 826 要素にて分割した．上部の金型 上面に作用する圧力を制御することにより，ガラスレ ンズの成形過程を模擬する. 数值解析には沉用有限要 素法コード ANSYS ver.8.0を用い, 大変形を考虑し た非線形接触解析を実施した. なお，予備計算を行っ た結果, 金型とガラス材との間に生じる摩擦力の影響 は相対的に小さいと判断されたため, 本論文では接触 部における摩擦係数を 0 として解析を行った.

ガラスの熱粘弾性特性は, 前節で導出したマスター カーブおよびシフトファクターを用いて与え, ポアン ン比は 0.3 とした. また, ガラスの線膨張倸数は 2.4 節 にて同定された值を用いた. 上下のプレス金型の材質 は超硬とし, ヤング率を $630[\mathrm{GPa}]$, ポアソン比を 0.2 , 線膨張係数は $4.6 \times 10^{-6}[1 / \mathrm{K}]$ とした. 温度条件および 圧力条件の異なる 2 つの典型的な成形プロセスを模擬
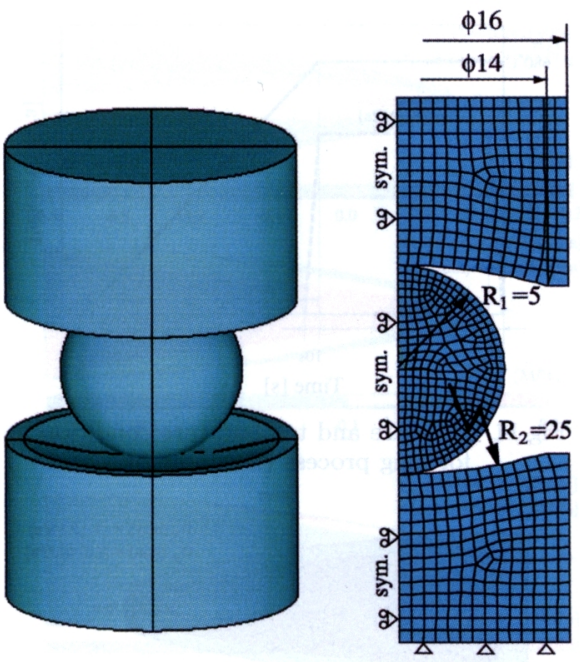

Fig.9 Analyzed model for FEM analysis.

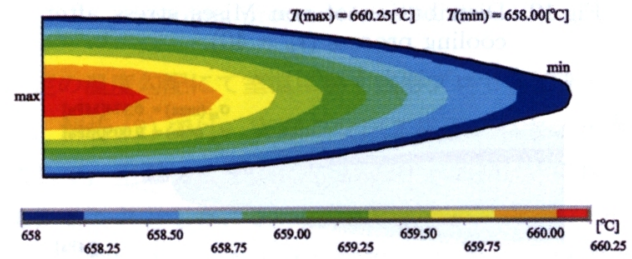

Fig.10 Distribution of temperature in a glass lens.

した数值シミュレーションを行い，それぞれの計算結 果を示すこととする.

なお，実際の成形においては，ガラスと金型，さら にはその外部領域との間で熱のやりとりが生じ, 結果 としてガラスレンズの内部に温度分布が生じる.この 温度分布の影響を明らかにするために, 本研究ではプ レス成形過程に先立ち, 熱伝導問題に関する基䊙的な 数值シミュレーションを実施した.

$3 \cdot 2$ ガラスレンズの非定常熱伝型解析 はじ めに, プレス成形過程においてガラスレンズ内に生じ る温度分布の影響を定量的に把握するために, レンズ 形状のガラス材に対して非定常熱伝導解析を実施した. レンズ全体を $T_{g}=680\left[{ }^{\circ} \mathrm{C}\right]$ に熱した後, レンズの外 周の温度を 300 秒間にて室温 $\left(20\left[{ }^{\circ} \mathrm{C}\right]\right)$ まで降下させる こととし，熱拡散率を $4.5 \times 10^{-7}\left[\mathrm{~m}^{2} / \mathrm{s}\right]$ として計算を 行った. 当然ながら, 冷却速度が相対的に速ければ,ガ ラスレンズ内部と表面の温度差は大きくなり, 冷却速 度が十分に遅ければ, ガラス内部の温度差は比較的小 さくなると予想される.

熱伝導解析により得られた冷却開始直後の温度分布 コンターを図 10 に示す.このコンター図は, レンズ表 


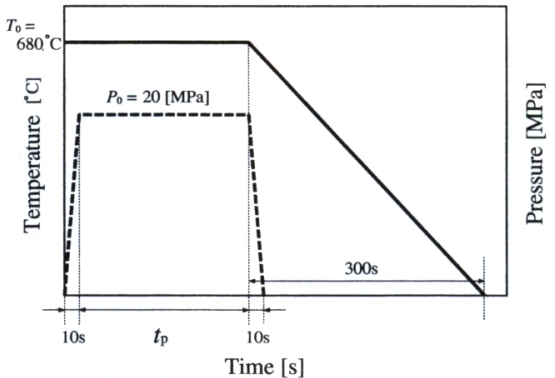

Fig.11 Pressure and temperature condition in forming process (Example 1).

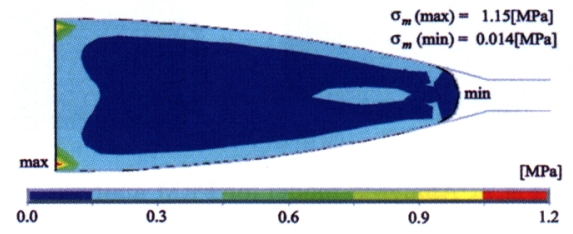

Fig.12 Distribution of von Mises stress after cooling process $\left(t_{p}=40\right)$.

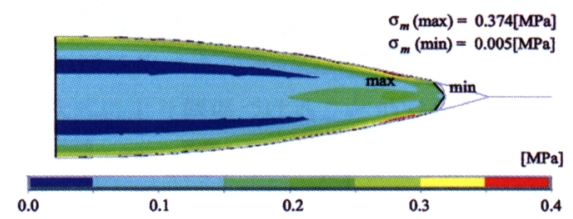

Fig.13 Distribution of von Mises stress after cooling process $\left(t_{p}=70\right)$.

面とレンズ内部との温度差が最も大きかった時刻の結 果を示した.

結果的に，レンズ内部とレンズ表面における最大温 度差は約 $2.2\left[{ }^{\circ} \mathrm{C}\right]$ であった. 本研究における解析温度 範囲が $600\left[{ }^{\circ} \mathrm{C}\right]$ 以上に及ぶことを考慮すれば, 熱伝導 に伴う温度差は十分に小さいものと判断できる. よっ て以降のプレス成形シミュレーションにおいては, ガ ラス内の温度分布の影響を無視することとした.すな わち，金型とガラス材において常に温度シーケンスに 一致した一様な温度場を仮定するものとし，物体内の 温度分布および熱の移動は考慮しないものとした。

$3 \cdot 3$ プレス成形解析 (1) まずはじめに, 図 11 に示される成形条件を用い, 数值シミュレーション を実施した。このプロセスでは，ガラス材と金型の温 度がともに $T_{0}=680\left[{ }^{\circ} \mathrm{C}\right]$ の状態から解析をスタート させる. 上側の金型上面に成形圧力 $P_{0}=20[\mathrm{MPa}]$ を 与えて $t_{p}$ 秒間保持し, 球形のガラス試料をレンズ状に 成形する. その後, 金型上面に作用する圧力を减じる とともに, 温度を室温 $\left(20\left[{ }^{\circ} \mathrm{C}\right]\right)$ まで降下させることと した. なお, 加圧および減圧の時間はともに 10 秒間と

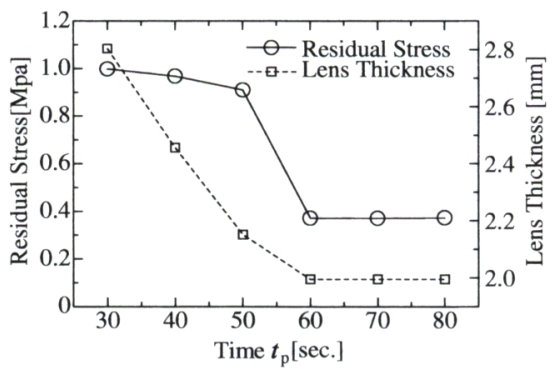

Fig.14 Relation between pressing time $t_{p}$, residual stress and lens thickness.

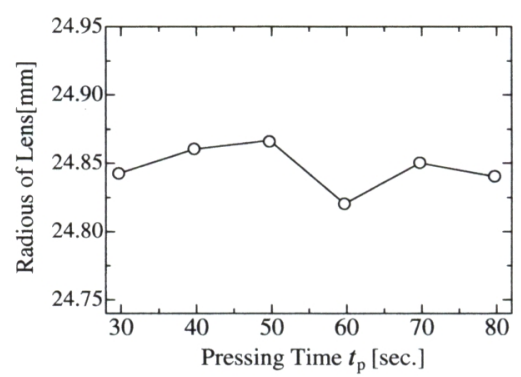

Fig.15 Relation between pressing time $t_{p}$ and radious of lens.

し，温度降下に要する時間は 300 秒とした．本解析で は, 圧力の作用時間, すなわち成形時間 $t_{p}$ を 30 秒か ら 80 秒まで変化させた場合のガラスの変形量と残留 応力について考察した。

図 12 および図 13 に, $t_{p}=40$ と $t_{p}=70$ の場合に おける成形終了後の Mises 相当応力の分布をそれぞれ 示す. $t_{p}=40$ の結果をみると, 上下の金型の間にす きまが生じており，成形時間が不足していることが確 認できる. また, $t_{p}=70$ の結果と比較して, レンズ 内部の相当応力の分布に明確な相違が認められる.

図 12 のように成形時間が短く, 上下の金型が接触 せずに成形が終了するケースでは，レンズの中心軸上 の，表面点からわずかに内側の位置において応力が最 大となる．他方，図 13 のように成形時間が長く，上下 の金型が接触するような成形を行った場合には，金型 と接するレンズ表層における応力が高くなる傾向を示 し, レンズ外周より約 $0.6[\mathrm{~mm}]$ の位置で相当応力が最 大なることが確かめられた.

図 14 は， $t_{p}$ を 30 秒から 80 秒まで 6 通りに変化さ せた場合について, 残留応力 (Mises 相当応力) の最大 值と, レンズ中心部の厚さの変化を図示したものであ る. 先に述べたように, $t_{p}$ が 60 秒以下の領域におい ては, 成形時間が短いことに起因して上下の金型が接 触せず, 結果としてレンズ厚さが設計寸法 $(2[\mathrm{~mm}])$ よ り大きくなる. 残留応力については $t_{p}$ が 60 秒に達す 


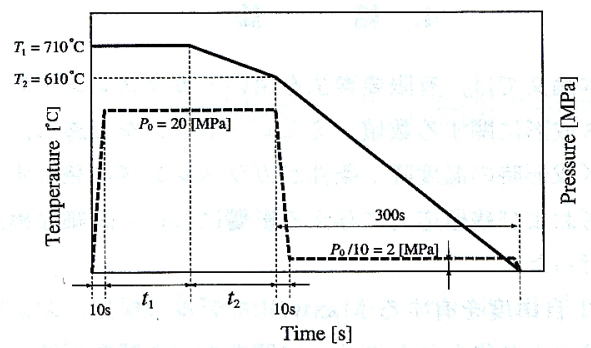

Fig.16 Pressure and temperature condition in forming process (Example 2).

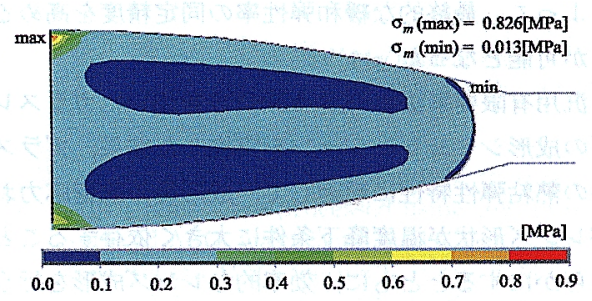

Fig.17 Distribution of von Mises stress after cooling process $\left(t_{1}=10, t_{2}=10\right)$.

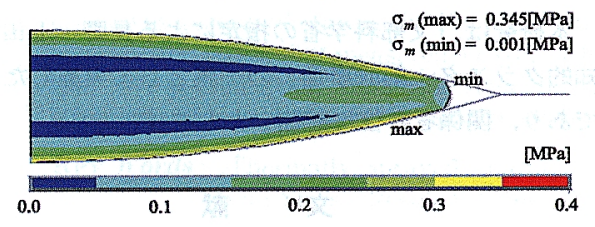

Fig.18 Distribution of von Mises stress after cooling process $\left(t_{1}=30, t_{2}=10\right)$.

るまでは，成形時間を増加させてゆくに従って残留応 力は減少する傾向を示す. $t_{p} \geq 60[\mathrm{~s}]$ の領域において は図 13 にて示したように応力の分布形状そのものが 変化するとともに，その最大値も $0.3[\mathrm{MPa}]$ 前後の一 定值に収束することが確かめられる。

図 15 は，レンズ中央部におけるレンズの曲率半径 と成形時閒 $t_{p}$ の関係である. 設計上のレンズ曲率半径 は $R=25[\mathrm{~mm}]$ であり，冷却に伴う熱収縮によって， 平均で約 $0.6 \%$ 程度の曲率変化が生じていることがわか る. また, $t_{p}=60[\mathrm{~s}]$ の近傍でその変化が極小となる 特徵的な傾向が確認できる.

$3 \cdot 4$ プレス成形解析 (2) 次に, 図 16 で示さ れるような成形プロセスにおける数值シミュレーショ ンの結果について示す. 解析 (2) では, 先程の解析 (1) と比較して成形温度を高く設定することで, 成形に要 する時間の短縮を図っている。

はじめに温度 $T_{1}=710\left[{ }^{\circ} \mathrm{C}\right]$ の状態において圧力 $P_{0}=20[\mathrm{MPa}]$ を金型上面に加え，その状態を $t_{1}$ 秒 間だけ保持する. 次に, 圧力はそのままに $t_{2}$ 秒閒で温 度を $T_{2}=610^{\circ} \mathrm{C}$ まで降下させる. その後 300 秒間,

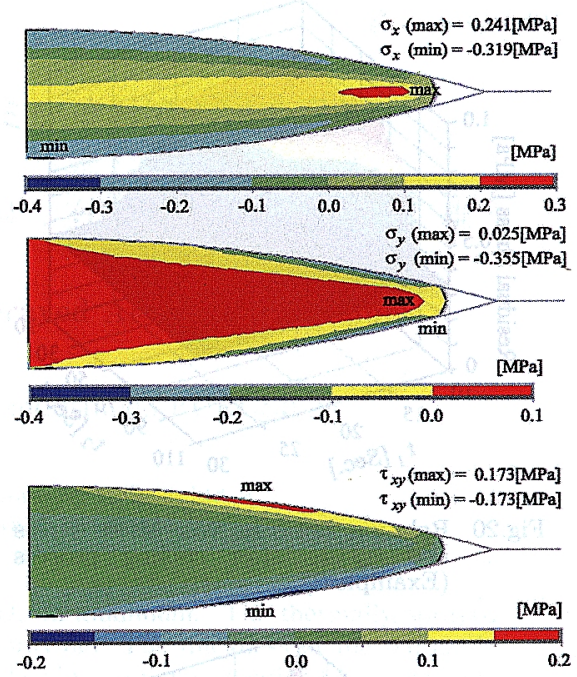

Fig.19 Distribution of stress $\sigma_{x}, \sigma_{y}, \tau_{x y}$ after cooling process $\left(t_{1}=30, t_{2}=10\right)$.

一定の温度勾配にて室温に戻す成形プロセスである. な お，解析 (2) では，実際のレンス成形プロセスを参考 にして，室温に戻す際にも $P_{0} / 10=2[\mathrm{MPa}]$ の保圧を 加えることとした. この解析では, 温度 $T_{1}=710\left[{ }^{\circ} \mathrm{C}\right]$ での保持時間 $t_{1}$, および温度 $T_{1}$ から $T_{2}$ まで降下させ るのに要する時間 $t_{2}$ を変化させ, 先の解析 $(1)$ と同様 にレンズの変形と残留応力に着目して考察した.

$t_{1}=10[\mathrm{~s}], t_{2}=10[\mathrm{~s}]$ の場合の残留応力の解析結果 を図 $17 に$ にさらに $t_{1}=30[\mathrm{~s}], t_{2}=10[\mathrm{~s}]$ の結果を図 18 にそれぞれ示す.いずれも成形終了後にレンズ内に 生じている Mises 相当応力の分布を示している. $t_{1}$ が 短い場合 (図 16) には，上下の金型が接触しない状態 で成形が終了するため，解析 (1) の図 12 とほぼ同様の 応力分布となることがわかる. 他方， $t_{1}$ を適切に設定 することによって，図 18 のように上下の金型が接触し た状態で成形が完了し，結果として図 13 にて示された 解析 (1) の場合とと同傾向の応力分布を示すことがわ かる。

なお, 解析 (1) の図 13 における最大応力值は約 0.374 [MPa], 解析 (2) の図 18 における応力の最大值は約 $0.345[\mathrm{MPa}]$ であった. 加圧時閒は前者が $t_{p}=70[\mathrm{~s}]$, 後者が $t_{1}+t_{2}=40[\mathrm{~s}]$ であるから，高い温度域でのプ レス時間を設定することにより，成形に要する総時閒 を短くすることが可能であると同時に，残留応力も小 さくすることが可能であるといえる.

また, $t_{1}=30[\mathrm{~s}], t_{2}=10[\mathrm{~s}]$ の場合について, 成形 終了後にレンズ内に生じている引張応力 $\sigma_{x}, \sigma_{y}$ および せん断応力 $\tau_{x y}$ の分布を図 19 に示す. レンズの内部に 


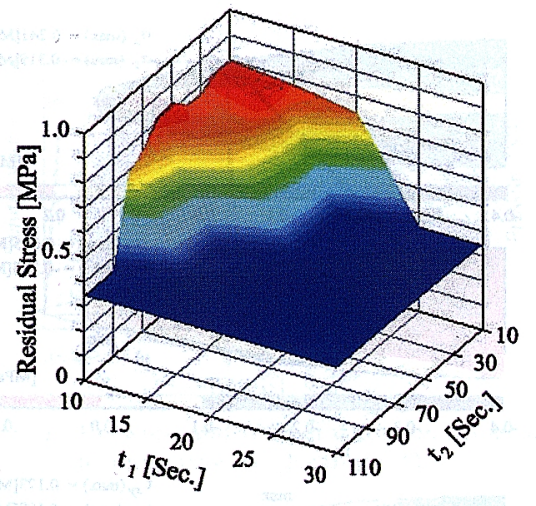

Fig.20 Relation between von Mises stress and $t_{1}, t_{2}$ after cooling process (Example 2).

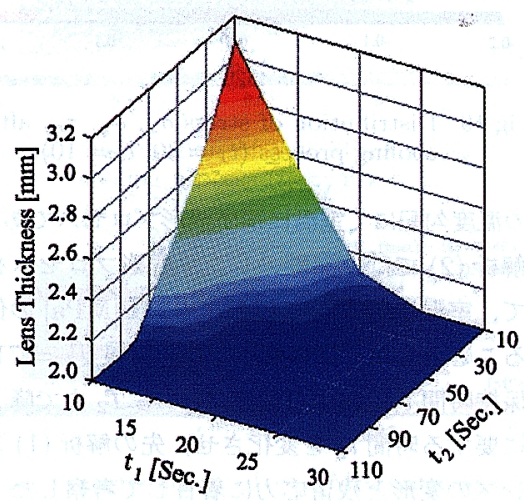

Fig.21 Relation between lens thickness and $t_{1}, t_{2}$ after cooling process (Example 2).

発生する応力は，引張応力が支配的であることが読み とれる．他方，レンズの表面点ではそれよりやや高い $0.3[\mathrm{MPa}]$ 程度の圧縮の残留応力が生じている様子が確 かめられる。

最後に， $t_{1}$ を 10 秒から 30 秒，また $t_{2}$ を 10 秒から 110 秒までそれぞれ変化させた場合について，成形終 了後の残留応力の最大值およびレンズ厚さと $t_{1}, t_{2}$ の 関係を図 20, 図 21 にそれぞれ示した.

図 20 の残留応力の結果についてみれば, $\left(t_{1}, t_{2}\right)=$ $(25,10)$ の点と $\left(t_{1}, t_{2}\right)=(10,90)$ の点を結ぶ線が, 成 形条件の良否を判断する境界線とみなすことができる. すなわち，この線を超える側の領域 $\left(t_{1}, t_{2}\right.$ が大きい側 $)$ にて $t_{1}, t_{2}$ を決定すれば，概ね寸法精度の高いガラス レンズの成形が可能であることがわかる. なお，グラ フより明らかに， $t_{2}$ よりも $t_{1}$ を長く設定するほうが， レンズの総成形時間を短縮する効果が高いことが確か められる.

\section{4. 結 論}

本論文では，有限要素法を用いてガラスレンズのプ レス成形に関する数值シミュレーションを実施し，レ ンズ成形時の温度降下条件がガラスレンズに発生する 変形および残留応力に与える影響について詳細な検討 を行った。

11 自由度を有する Maxwell モデルの採用，および 実験により得られたクリープ関数をべき関数近似した のちに解析的な Laplace 変換を施す一連の手法の導入 によって, 最終的な緩和弾性率の同定精度を高めるこ とが可能となった.

汎用有限要素法コード ANSYS を用いたガラスレン ズの成形シミュレーションを実施した結果，ガラス材 料の熱粘弾性特性に起因して，成形後の残留応力およ びレン成形状が温度降下条件に大きく依存することを ・明らかにするとともに，効率的なレンズ成形を行うた めの指針を示した。

\section{謝辞}

本研究は,「文部科学省の指定による長野・上田地域 知的クラスター創成事業」の一環として実施したもの であり，関倸者各位に感謝いたします。

\section{文献}

(1) Umetani, M., Manufacturing of Optical Glass Lens by Press-Molding Method, New Glass, Vol.13, No.2, (1998), pp.32-37.

(2) Arai, M., Yamamoto, K., Matsuba, I., Matsukura, T., Sugimoto, K., Numerical Simulation of Forming Process of Glass-Lens Using Thermo-Viscoelastic Model, Transactions of the Japan Society for Computational Methods in Engineering, Vol.3, (2003), pp.39-44.

(3) Klyuchnikov, N., Science of Glass (in Japanese), trans. by Chino, H., (1972), TokyoTosho.

(4) Holloway, D.G., Physics of Glass (in Japanese), trans. by Ooi, K., (1977), KYORITSU SHUPPAN.

(5) Yamada, Y., Plasticity and Viscoelasticity (in Japanese), Series of Basis and Application of Finite Element Methods 6, (1980), BAIFUKAN.

(6) Morland, L. W. and Lee, E. H., Stress Analysis for Linear Viscoelastic Materials with Temperature Variation, Transaction of the Society of Rheology, Vol.4, (1960), pp.233-263.

(7) Murakami, K., Basic theory of Rheology (in Japanese), (1991), pp.151-170, SANGYO-TOSHO.

(8) Arai, M., Shibata, K., Adachi, T., Analysis of Residual Stress in Thermo-Viscoelastic Materials by Boundary Element Method, Transactions of the JASCOME Journal of Boundary Element Methods, Vol.15, (1998), pp.29-34.

( 9 ) Hosono, T., Fast Laplace Transform by BASIC (in Japanese), (1984), KYORITSU SHUPPAN.

(10) O. S. Narayanaswamy, A Model of Structural Relaxation in Glass, Journal of the American Ceramic Society, Vol.54, No.10, (1971), pp.491-498. 